\title{
ECOLINGUISTIC STUDY OF CONSERVATION NEWS TEXTS IN INDONESIAN MASS MEDIA
}

\author{
Tommi Yuniawan \\ Universitas Negeri Semarang, Indonesia \\ tommiyuniawan@mail.unnes.ac.id \\ DOI: https://doi.org/10.24071/ijhs.2018.010203 \\ received 19 September 2017; revised 30 December 2017; accepted 19 February 2018
}

\begin{abstract}
This study aims to describe the study of ecolinguistics in the conservation news text in Indonesian mass media. The study of ecolinguistics examines discourse texts pertaining to the environment. The environmental discourse with all its embodiments (oral text, written text, images and internet) is called green texts. Green texts can be found in the consolidated news text in the mass media. This text contains a language expression of conservation events or issues relating to the vision of a conservation-oriented university. The research used descriptive qualitative method. This research data in the form of lingual unit of news fragment of conservation news sourced from mass media of Indonesia which is relatively many. Methods of data collection are done by referring the method, literature study method, and documentation method. Furthermore, the data were analyzed by using the method of comparison and contrast. Based on the results of the analysis and discussion, it is concluded that in the conservation news text in Indonesian mass media, it is found that ecolexicon in the texts are in the form of (a) base word, (b) derivative words, (c) noun phrases, (d) verbal phrases, and (e) adjective phrases. The results of this study are expected to contribute theoretically and practically to the field of linguistics, language learning, journalism, and public policy.
\end{abstract}

Keywords: ecolinguistics, ecolexicon, mass media, Indonesia conservation news text

\section{Introduction}

Discourse is a linguistic unit of the most complete element that is composed of sentences or sentences, both oral and written, which form a harmonious and unified understanding (Rustono, 1999, p.21). Furthermore, according to Suhandang (2004, p.102), news (news) is derived from Sanskrit, namely Vrit (translated in English: "write") which means 'there' or 'happened'. Rokhman and Surahmat $(2016$, p.243) assert that the reality of news is created from the journalist's understanding of the actual events that occur and are spoken back through oral or written forms. The news of published conservationist universities derives from messages or information that use symbols, relating to interpretations and events, within a broad societal system. This news is assumed to contain 
information that is reasonably available to the public because the information submitted is factual, actual, accurate, objective, important, and attracts public attention. This is in line with Kress' theory (2010, p.126) which states that the mass media serves as a tool for reporting various categories of events that occur in the community.

The text of conservation news in the mass media is a lingual phenomenon. In its form as text, conservation news is not just a linguistic phenomenon (lingual structure), but also as a mind building (cognitive structure) as well as action building (action structure). Opinion of the media institution revealed in the news must be influenced or determined by the media institution and its social context. Therefore, the study of conservation news texts on the one hand becomes an opportunity to interdisciplinary language study and on the other hand can add to the understanding that news is a complex structure of language, thought, action, and social construction. Mass media have properties or characteristics that are able to reach in large and wide publicity and able to give the popularity of what is preached in the mass media.

Accordingly the conservation texts correspond to the relationship between language and ideology. Conservation is one of the important news topics in society. Topics on this matter are in the Suistanable Development Goals (SDGs) which are the result of an agreement of more than 190 member states of the United Nations (UN) applicable 2016-2030 (UNDP 2015) resuming Millennium Development Goals (MDGs) 2000-2015. In Indonesia, the issue of conservation is also a priority development under Nawacita's policy outlined in the 2015-2019 National Medium-Term Development Plan. Conservation becomes an important issue in news media coverage. Although conservation news is an important issue, conservation issues are particularly sensitive to Indonesian society. This is because it is commonly associated with institutional policies or ideologies.

In addition, conservation news texts are related to the relationship between language and the environment. This is consistent with the opinion of Fill and Mushausler (2001, p.3) states that there are four things that allow the relationship between language and environment, namely: (1) language is free and full of meaning; (2) language created by the world; (3) the world is created by language (the structuralist and post-structuralist view); (4) the language is interconnected with the world (both are arranged and arranged but sometimes also free). The mutual change between environment and language is studied through ecolinguistic studies. Ecolinguistic studies examine ecosystems that are part of the human life system (ecology) with the language humans use to communicate in their environment (linguistics). In this case, Sapir (in Fill \& Muhlhausler, 2001, p. 14), mentions that there are three forms of environment. First is the physical environment that includes geographic characters such as the topography of a country (either beaches, valleys, highlands or mountains, weather conditions, and the amount of rainfall). Second is the economic environment (basic human needs) consisting of fauna, flora, and mineral resources. Third is the social environment that surrounds the various forces that exist in society that shape the lives and minds of the people to each other. According to Al-Gayoni (2012, p.25), environmental changes also affect the use of language speakers. Therefore, the focus of this research is on ecolinguistic studies in conservation news texts in Indonesian language mass media. 
Ecolinguistics existed since the 1970s when Haugen (1972) proposed a theoretical conceptual framework with a number of linguists, compiled in The Ecology of Language. According to Haugen (in Fill \& Muhlhausler 2001, p.57), language ecology is the study of existing inter-language interactions with the environment. Understanding the environment in ecolinguistics leads to the opinion of Sapir (in Fill \& Muhlhausler, 2001, p.14), the physical and social environment. The physical environment involves physical geography: the topography of a country (coastal, valley, land, highland, mountain) climate, and intensity of rainfall, the economic basis of human life comprising fauna, flora and mineral resources; While the social environment consists of the various forces of society that make up the minds and lives of every individual among them: religion, ethics, forms of political organization, and art.

Fill and Mushausler (2001, p.11) argue that ecolinguistics is applied linguistics that is cross-cutting (interdisciplinary). Furthermore, they (p.51) explain that ecolinguistics as a broader study of its scope in studying syntax, semantics, and pragmatics, and hence the need for some innovative new theory to investigate these ideas empirically. According to Crystal (2008, pp.161-162), Ecolinguistics is a study that reflects the nature of ecology in biological studies, in which the interaction between language and cultural environment is seen as the core: it is also called the language ecology, linguistic ecology and sometimes green linguistics. Alexander and Stibbe (2010) define Ecolinguistics as a study of the impact of language use in survival that bridges relationships between humans, other organisms, and the physical environment that is normatively oriented towards the preservation of sustainable relationships and life.

Thus, ecolinguistics is closely related to how language serves to mold, nurture, influence or destroy relationships between people, living conditions, and the environment. This is the case with the opinion of Stibbe (2010, p.1), ecolinguistics evolved as a result of human ecological development associated with various systems (economic, social, religious, cultural, linguistic, and ecosystem systems) that are interdependent and related to one another.

Based on the above information, it is concluded that the study of ecolinguistics has parameters, namely interrelationships (language and environment interrelation), environment and Haugen's diversity (diversity of language and environment) (in Fill \& Muhlhausler 2001, p.1). Haugen (1972) (in Mbete, 2009, pp.11-12), states that ecolinguistics has links to ten study spaces, namely: (1) comparative historical linguistics; (2) demographic linguistics; (3) sociolinguistics; (4) dialinguistik; (5) dialectology; (6) philology; (7) prescriptive linguistics; (8) glotopolytics; (9) ethnolinguistics, anthropological linguistics or cultural linguistics (cultural linguistics); And (10) the typology of languages in an environment.

In the scope of an ecolinguistic study, living and used languages illustrate, represent, symbolically-verbal representation in the environment, both the social environment and the socio-cultural environment. It implies language changes as the social and environmental changes change, as Liebert (2001) (in Mbete, 2009, p.7) states that '... language change ... represents ecological changes'. The process of change in the language runs in stages for a long time, unknowingly by its speakers, and is inevitable. 
In addition, Sapir (in Fill \& Muhlhausler, 2001, p.2) states that within the scope of ecolinguistics, language and environmental relations exist only on the level of the lexicon, not, for example, at the phonological or morphological level of this interrelation exists merely on the level of the vocabulary and Notes, for example, on that of phonology or morphology. 'This can be presented in the Bang and Door Dialog Model chart (Bang \& Door, 1996, p.47).

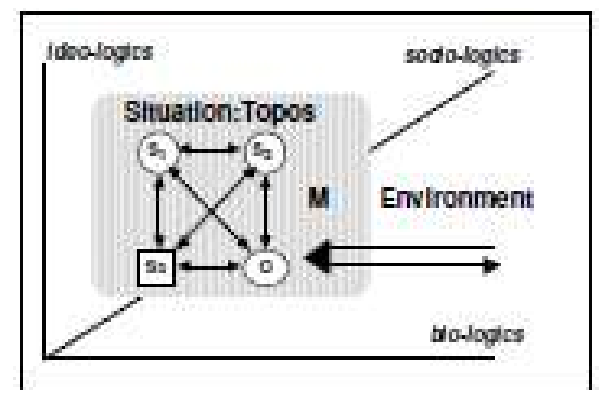

Figure 1: Dialogical 3D Social Practice of Bang \& Door

Source: (Lindo \& Bundegaard 2000)

Mbete (2002) conducted research on 'Verbal Expressions in Lio and Its Functions in Preserving the Environment'. Mbete studies the form, meaning, and function contained in verbal expressions relating to environmental preservation. The findings in the study of Mbete are verbal expressions that function in the preservation of the environment consisting of: (1) expressions relating to the universe; (2) phrases relating to land cultivation; (3) expressions pertaining to the preservation of mini-protected forests and water sources; (4) phrases related to coastal and marine conservation; (5) expressions relating to preservation and compatibility; And (6) expressions relating to the relationship between Lio's ethnic group. Mbete's research has an equation on the focus of form analysis and the meaning of linguistic elements. The difference in the data was taken in the form of verbal expressions in the context of Po'o ritual (pest ritual rejection), while this research used data in the form of fragmented texts of Indonesian language conservation news in mass media.

Research that has the same study object with this research was also conducted by al-Sharabi et.al. (2011) entitled 'Representation of Early Marriage Phenomenon in Yemen Community: an Analysis of Critical Discourse from the English Yemen newspaper'. Al-Sharabi identified the texts of the newspaper to find out the representation of early marriage in Yemen society. Al-Sharabi uses critical discourse analysis from Fairclough and also a multimodal-based critical discourse analysis from Kress and van Leeuwen. Another researcher analyzing the news text is Duc Duy Vo (2013) entitled 'Language and Ideology in English and Vietnamese News Text - A Comparative Study'. This study uses critical discourse analysis from Fariclough and transitivity systems in linguistic functional systems. A total of 25 English texts and 25 Vietnamese texts were analyzed by the analytical tool. In addition, Bolted and Conch (2014), also analyzed the news text in the newspaper in the network (online). Their research entitled Refugee Exchange Transactions in Text News in Network (online): Ideology and Representation. News texts are taken from three English-language Malaysian 
newspapers: The Star, The New Straits Times (NST), and Malaysiakini. This study uses critical discourse analysis from Fairclough to know the representation of ideology and context in shaping the discourse. From the above explanation, it can be concluded that the news text can be analyzed with various analytical blades as well as critical discourse analysis and functional system linguistics. This research analyzed conservation news text in mass media with analysis knife in the form of ekolinguistik.

Then, ecolinguistic research was conducted by Kesuma (2015) entitled 'The vulnerability of the Ekoagraris Leksikon in Angkola / Mandailing Language: Ecolinguistic Studies'. The study aims to describe the existence of eco-vagrant lexic that is still used by the community in Angkola / Mandailing and the cultural values and environmental wisdom contained in the eco-vagrant lexicon in the area, especially in Sayurmatinggi sub-district. The research is qualitative and quantitative descriptive research. The data used to support the research is taken by interviewing, observation, questionnaire distribution, and utilizing existing literature. The research data are lexicon of verbs, nouns, and adjectives associated with rice field lexicon and cultivation in Sayurmatinggi Sub-district. The above research has in common with research to be done in terms of the use of ecolinguistic studies and focusing the topic on the lexicon. In Kesuma research, data sources were obtained from the Angkola / Mandailing community and the cultural values and environmental wisdom contained in the eco-tourism lexicon in Sayurmatinggi area. The data source in this research is conservation news text in Indonesian language mass media.

At the level of the lexicon, the dynamics and language changes are influenced by three dimensions (Lindo \& Bundegaard, 2000, pp.10-11), namely: (a) ideological dimension, ie the ideology or adicita of the society eg the ideology of capitalism supported by the market ideology, To environmental resources, such as the emergence of terms and discourses of exploitation, growth, economic gain. So there are efforts to maintain, develop, and cultivate certain species of fish or plants of high economic value and strong; (B) sociological dimension, namely the activity of discourse, dialogue, and social discourse to realize the ideology. In this dimension language is a meaningful social practical form; And (c) the biological dimension, due to the diversity of lake biota (or sea, or land) equally within the ecosystem, and with the vitality of species and life-force that differ from one another; There is a large and strong so dominate and 'eat' the weak and small, there is a small and weak so marginalized and inedible. The biological dimension is verbally recorded in lexicon in the word language of each language so that the entities are signified and understood. Language units in the form of words, phrases or units of language expressions containing information about the meaning of the language units that describe the conservation environment are called conservation ekoleksikon.

From that theoretical framework, in an ecolinguistic perspective, the language of the environment and the language environment as a metaphorical expression illustrates the comparison of linguistic to the environmental science (ecology) (Mbete, 2009, p.8). This implies that ecolinguistic perspectives can be offered as an approach to rescue, protection, empowerment, and preservation of regional languages as a mother tongue for some of the nation's children, as well as Indonesian language as a means of developing Indonesian culture. Nationally, 
without prejudice to regional languages, the empowerment, protection and preservation of the Indonesian language as the national language and language of the State should take precedence.

Language is a picture of the reality that exist in the environment. The biological dimension of the environment with the diversity of its interacting entities is the focus and focus of ecological studies. Analogously, the biological dimension, in addition to the sociological and ideological dimensions of linguistic phenomena in the dialectic of ekolingustik applied by Bang and Door (2000), is used in the framework of dissecting the meanings and ecological values of languages, in particular looking at and dissecting the phenomenon of language in an ecolinguistic perspective. Diversity, interaction, interrelation, and holistic, becomes an ecolinguistic framework.

\section{Method}

This research uses qualitative research approach. The use of this approach is in accordance with the philosophy of positivism which views that science is built empirically. Then, abstraction and drawing conclusions are based on the results of the analysis of the empirical facts obtained in the field. The qualitative of this research is related with the research data in the form of quality of lingual unit in conservation news text in Indonesian language mass media. This study also uses descriptive approach. This is related to the goal to be achieved in this research, which is to describe the conservation news text in the mass media from the study of ecolinguistics.

This research uses ecolinguistic design. Fill (2001, p.126) in Lindo \& Bundsgaard (2000) states that ecolinguistics is an umbrella against all approaches of language study in combination with the environment (ecology). For that reason, in ecolinguistics, context is any background knowledge that is assumed shared by a speech community. The context in ecolinguistics includes: (a) ideological dimension, ie the existence of ideology or adicita of society, (b) sociological dimension, namely the activity of discourse, dialogue, and social discourse to realize the ideology. In this dimension language is a meaningful social practical form, and (c) a biological dimension, related to diversity in ecosystems verbally recorded on lexicon in the lingual unit of the universe so that the entities are signified and understood.

This research data are in the form of conservation news texts from Indonesian mass media. Sources of data used, is preaching of conservationoriented universities from www.unnes.ac.id page, Suara Merdeka newspaper, Kompas newspaper from 2010 to 2017. Furthermore, identification method used in this sorting activity data. Identification means the determination or identification of the data collected in the data corpus. In addition to that method, in data sorting activities are also used classification method. The classification in this study means the classification of data based on similarities and differences in data identity. With this method, the identified data will be classified. Then, the data sorting activity is the research stage which is done after the data collection. In this activity will be used criteria as the basis of sorting.

There are four methods of data collection conducted in this research that is simak method, literature study method, documentation method and questionnaire method (Sudaryanto, 2015, p.13; Mahsun 2005, p.133; Kesuma 2007, p.43). 
Furthermore, instrument or research tool used in this research is human instrument (human instrument) or researcher itself. This is in line with Moloeng's (2007: 8) assertion that in qualitative research, the key instrument is the reviewer or the researcher himself, so the researcher must be 'validated'.

Validation done to the researchers, including: understanding of qualitative descriptive research methods, mastery of insight into the field of scientists studied, the readiness of researchers to enter the object of research. Qualitative researchers as human instruments function to set the focus of research, selecting informants as data sources, collecting data, assessing data quality, analyzing data, interpreting data, and making conclusions on its findings (Sugiyono, 2012, p.306).

Then the data has been collected analyzed in accordance with the formulation of problems and research objectives by using methods of matching and agih. The method is the method of research that uses the determinants of the language in question. Another term of the agih method is the distribusional method. The method of research is the method of research that the means of penentunya is outside, regardless and not become part of the language in question (Sudaryanto, 2015, p.13; Mahsun, 2005, p.112; Kesuma, 2007, p.47).

\section{Findings and Discussion}

The analysis of conservation news texts in Indonesian mass media in ecolinguistic study is not merely to analyze microstructure language only. The analysis of conservation news texts in Indonesian language mass media also discusses the issues of language macrostructure such as language style, euphemism, dysphism, personification, metaphor, and others. The text of conservation news in Indonesian mass media is constructed for certain purposes and purposes. Sometimes the text is used for campaigns or socialization of environmental preservation, imaging, and criticism of individuals who play a role in environmental damage. Conservation news texts uploaded or published in the mass media are presented in the following data.

\section{News Text 1}

CSR di Boyolali, Terbentuk Empat Kelompok Tani (CSR in Boyolali, Four Farmer Communities are Established)

(Wednesday, $30^{\text {th }}$ of March 2011, source: www.unnes.ac.id)

Program Corporate Social Responsibility (CSR) Universitas Negeri Semarang (Unnes) kerja sama dengan Pertamina di Kabupaten Boyolali pada tahun pertama ini berhasil membentuk empat kelompok tani dengan anggota per kelompok 70 - 80 orang. Desa binaan tersebut berada di Ketaon, Kecamatan Banyudono. (p1)

Margunani, MP ketua tim saat kunjungan Rektor Unnes, Minggu (27/3), di Boyolali menyatakan pihaknya menyerahkan bantuan alat berupa satu mesin perajang sampah, tiga set alat pemipil jagung, tiga set alat pembuat tepung jagung, dan 20 set alat pembuat kompos Tasakura. 
"Selain itu, tiga set tong sampah pemilah sampah organik dan anorganik, alat memasak untuk membuat kue dari jagung (kompor, blender, mixer, open, dan lainnya masing-masing tiga set," kata Margunani. (p2)

The Corporate Social Responsibility (CSR) Program of Semarang State University (Unnes) in cooperation with Pertamina in Boyolali Regency in the first year was successfully established four farmer groups with members per group of 70 - 80 people. The target villages are located in Ketaon, Banyudono Sub-district. (P1)

Margunani, MP team leader during the visit of Unnes Rector on Sunday (27/3), in Boyolali stated that his party handed over a tool aid in the form of one garbage chopper machine, three sets of corn shrimp, three sets of cornmeal and 20 sets of compost maker Tasakura. 'In addition, three sets of organic and inorganic waste disposal garbage cans, cooking utensils for making cakes from corn (stoves, blenders, mixers, open, and others each three sets, 'Margunani said.

\section{News Text II}

SBY: Unnes Bagus Sekali, Ini Baru Konservasi (SBY: Unnes is excellent. This is conservation university)

(Wednesday, $30^{\text {th }}$ of March 2016, sourcer: webpage www.unnes.ac.id.)

Inilah komentar Presiden RI ke-6 Prof Dr Susilo Bambang Yudhoyono ketika memasuki Auditorium Universitas Negeri Semarang (Unnes) kampus Sekaran, pada Rabu (30/3).“Luar biasa! Bagus sekali. Ini baru konservasi!” katanya yang segera disambut jabat tangan Rektor Unnes Prof Dr Fathur Rokhman MHum. (p1)

This is the comment of President of the 6th RI Prof. Dr. Susilo Bambang Yudhoyono when entering the State University of Semarang (Unnes) Auditorium of Sekaran campus, on Wednesday (30/3). Very good. This is new conservation!'He said who was immediately greeted by the handshake Unnes Rector Prof. Dr. Fathur Rokhman MHum. (P1)

\section{News Text III}

Gandeng Pertamina, Unnes Tanam 200 Pohon di Kelurahan Kandri (Collaborating with Pertamina, Unnes Planted 200 Trees ar Kandri) (Monday, $8^{\text {th }}$ of December 2014, source: Suara Merdeka)

SEMARANG - Belum lama ini, Universitas Negeri Semarang (Unnes) bekerja sama dengan Pertamina dan Pemerintah Kota Semarang menanam pohon di Kelurahan Kandri, Gunungpati, Semarang. (p1) 
Kegiatan ini merupakan kerja sama Universitas Negeri Semarang melalui Lembaga Penelitian dan Pengabdian kepada Masyarakat (LP2M) dengan Pertamina dan Pemerintah Kota Semarang dalam Progam Kemitraan Bina Lingkungan (PKBL). Seperti dilansir dari laman resmi Unnes, kegiatan penanaman 200 pohon, yang meliputi jambu krital, durian, dan kelengkeng, ini melibatkan banyak pihak. Yakni General Manager Marketing Operasional Region IV pertamina, Area Manager SME dan SR partnership, pemimpin wilayah bank bni, rektor, kepala badan, kepala dinas, camat dan lurah setempat. (p2)

Adapun maksud dari program ini adalah pembentukan desa eduwisata dan kawasan ekonomi masyarakat dan diharapkan dapat menjadi daerah agrowisata dan juga dapat digunakan siswa sekolah untuk belajar. (p3)

Kepala Dinas Pertanian WP. Rusdiana mengatakan, potensi seperti ini harus digali terus, dan ini adalah peluang Kota Semarang untuk memajukan desa wisata, yang akan menjadi desa wisata baru dengan potensi-potensi lokal. (p4)

Dia mengatakan, daerah Mijen dan Gunungpati merupakan daerah perkembangan pertanian, baik peternakan maupun pangan, hortikultura, herbal, dan tanaman hias. Rencananya, kebun dinas di Kandri tersebut adalah satu tempat yang rencana akan dinamai rumah pintar petani yang dapat digunakan untuk tempat berkumpul dan dapat berkontribusi untuk Pemerintah Kota Semarang. (p5)

Rektor Universitas Negeri Semarang Prof Dr Fathur Rokhman MHum mengatakan, potensi daerah seperti mangga, jambu, rambutan, durian perlu dikonservasi. Efeknya bisa sebagai penyanggah air dan juga habitat hewan. Untuk itu upaya ke depan adalah pemeliharaan dan Unnes akan membantu pemasaran. (p6)

SEMARANG - Recently, Semarang State University (Unnes) in collaboration with Pertamina and Semarang City Government planted trees in Kelurahan Kandri, Gunungpati, Semarang. (P1)

This activity is a collaboration between Semarang State University through Institute of Research and Community Service (LP2M) with Pertamina and Semarang City Government in Partnership Program of Community Development (PKBL). As quoted from the official website of Unnes, the planting activities of 200 trees, which includes guava, durian, and kelengkeng, this involves many parties. Namely General Manager Marketing Operations Region IV Pertamina, Area Manager SME and SR partnership, the 
leader of the bank bni, rector, head of agency, head of department, subdistrict and local lurah. (P2)

The purpose of this program is the establishment of eduwisata village and the economic area of the community and is expected to become an agro-tourism area and can also be used by school students to learn. (P3)

Head of Agricultural Service WP. Rusdiana said this potential should be explored, and this is an opportunity for Semarang City to advance the tourist village, which will become a new tourist village with local potentials. (P4)

He said the Mijen and Gunungpati areas are areas of agricultural development, both livestock and food, horticulture, herbs, and ornamental plants. According to the plan, the official gardens in Kandri are one place where plans will be named smart farmers' homes that can be used for gathering places and can contribute to Semarang City Government. (P5)

Rector of State University of Semarang, Prof. Dr. Fathur Rokhman MHum said that regional potencies such as mango, jambu, rambutan, durian need to be conserved. The effect can be as a buffer of water and also the habitat of animals. For that future effort is maintenance and Unnes will help marketing. (P6)

\section{News Text IV}

Lingkungan Kampus, Sehat dengan Bersepeda (Campus Environment, Hearlthy with Cycling)

(Tuesday, $4^{\text {th }}$ of March 2014, source: KOMPAS)

Memasuki lingkungan kampus Universitas Negeri Semarang di Sekaran, Gunungpati, Semarang, Jawa Tengah, kesejukan menyergap. Rimbun pepohonan menyambut. Petugas satpam berjaga di depan gerbang dan mengarahkan sepeda motor atau mobil untuk diparkir sebelum memasuki kawasan kampus. (p1)

Rektor Unnes Fathurrahman mengungkapkan, kebijakan berjalan kaki dan bersepeda di kampus merupakan salah satu bagian dari komitmen Unnes sebagai universitas konservasi. "Ini menjadi kontribusi kami sebagai lembaga pendidikan untuk ikut mengatasi masalah pemanasan global. Upaya konservasi sudah masuk dalam statuta Unnes sejak 2010," ujarnya. (p9)

Setiap mahasiswa diwajibkan menanam minimal satu pohon. Pohon itu menjadi syarat bagi mahasiswa yang akan mengerjakan skripsi. (p10) 
Entering the campus environment of Semarang State University in Sekaran, Gunungpati, Semarang, Central Java, coolness ambushed. Rimbun trees welcome. The security guard guards in front of the gate and directs the motorcycle or car to park before entering the campus. (P1)

Rector Unnes Fathurrahman revealed, the policy of walking and cycling on campus is one part of Unnes's commitment as a conservation university. 'This is our contribution as an educational institution to help overcome the problem of global warming. Conservation efforts have been included in Unnes's statute since 2010, 'he said. (P9)

Each student is required to plant at least one tree. The tree is a requirement for students who will do thesis. (P10).

The four news texts above are conservation news texts. This is because the four examples of news texts show that the mass media in this case, namely the page www.unnes.ac.id, Suara Merdeka, and Kompas using linguistic units in the form of news texts about the university conservation as a means of building reader opinion. For that, in the news in the mass media found the text of conservation news. This indicates a link between language and environment.

The news text I informs the success of an institution to form a farmer group in Boyolali District. In the news, the ecolips are emerging among them, namely compost, organic, inorganic, and trash cans, garbage sorting. Then, in the second news text, the subject of conservation-oriented universities is getting stronger. This is demonstrated by the recognition of the 6th President of the Republic of Indonesia, Mr. Susilo Bambang Yudhoyono, who stated 'Unbelievable! Very good. This is new conservation! '. In fact, there is a message from this news text, so that other universities can follow what has been done by UNNES. This shows that conservation-based universities provide a positive. It seems that conservationminded universities will become a trendsetter that will be followed by other universities. This shows the existence of a linguistic expression of euphemism.

In the third news text, there is a message to be conveyed that efforts to create an atmosphere of conservation is needed cooperation with other instusi, namely pertamina. This report shows that to imaged and repute conservationbased universities need to involve parties outside the campus. In addition, there is an interesting linggual unit of this news, namely Pertamina tandem, Unnes Plant 200 Trees in Kandri Village. The use of the word choice is usually done to humans or people, for example: 'Mother took my sister', 'Daddy took my grandmother'. But in the text, the word coupled with the word pertamina. This shows that in the text of conservation news in mass media can be found the existence of linguistic expression in the form of metaphor.

Furthermore, in the news text IV, there is a message to be conveyed that one of the pillars in the conservation of Natural Resources and the environment also received special attention. The policy of transporting by bicycle in the campus area becomes a movement conducted at conservation-minded universities. On the other hand, this condition is juxtaposed with several other universities. Each 
cycling policy in a college campus environment has its advantages and problems. In addition, lingual units of coolness phrases ambushed, lush trees welcome, as well as sterile from motor vehicles indicate the choice of words that utilize the expression of language in the form of personification. This personification becomes a beauty in packing news about Campus Healthy Environment with Cycling, which is a sympathetic invitation to all campus residents.

Trampe in Fill and Muhlhausler (2001, pp.238-239) states that environmental discourse or green discourse in mass media usually contains: (1) reification, which is to treat living beings as objects of economic value, related to technology and ideology. For example, living things or resources can be produced, optimized, managed, and used (utilized); (2) to hide the fact, ie the use of euphemism to replace some words or terms that are avoided. For example, relating to death, destruction or destruction, extermination or destruction, and poison; (3) to express hatred or opposition to parties that damage traditional or customary land; And (4) create slogans and elements that convey ideas and ideas used to make the process of environmental and cultural destruction undertaken by a group of people appear to fit and conform with the laws of nature.

Furthermore, the analysis of all four headings above can be classified into an analysis of ecolexic forms. In conservation news texts, the forms of ecoleksikon are classified into three pillars of conservation, namely (a) pillars of values and pillars, (b) pillars of art and culture, (c) natural and ecological resources consisting of three forms, namely ecoleksikon in the form of (a) Words, (b) derivative words, and (c) phrases.

\section{The Ecolexicon Forms of Pillars of Values and Characters}

The pillars of values and character are the conservation values associated with the embodiment of values, personality traits, and self-development. Here is the ecolexico form of the pillars of values and characters found in the conservation news text in Indonesian-language mass media.

Tabel 1: Ecolexicons of Words

\begin{tabular}{|c|c|c|c|c|}
\hline \multirow{2}{*}{ Ecolexicon } & \multirow{2}{*}{ Categories } & \multirow{2}{*}{ Meaning } & \multicolumn{2}{|c|}{ Referent } \\
\hline & & & Biotic & Abiotic \\
\hline $\begin{array}{l}\text { Humanis } \\
\text { (humanist) }\end{array}$ & noun & $\begin{array}{l}\text { People who crave and strive } \\
\text { for a better life, based on the } \\
\text { principle of humanity. }\end{array}$ & - & Abiotic \\
\hline $\begin{array}{l}\text { Integritas } \\
\text { (integrity) }\end{array}$ & noun & $\begin{array}{l}\text { Quality of nature, or } \\
\text { circumstances that show a } \\
\text { unified whole so as to have } \\
\text { the potential and ability that } \\
\text { emit dignity. }\end{array}$ & - & Abiotic \\
\hline $\begin{array}{l}\text { Inovatif } \\
\text { (innovative) }\end{array}$ & Adjective & $\begin{array}{l}\text { Introducing something new; Is } \\
\text { renewal (new creations). }\end{array}$ & - & Abiotic \\
\hline $\begin{array}{l}\text { Inspiratif } \\
\text { (inspiring) }\end{array}$ & Adjective & $\begin{array}{l}\text { Something that can give the } \\
\text { effect of the spirit and power.. }\end{array}$ & - & Abiotic \\
\hline
\end{tabular}


Table 2: Ecolexicons of Derivations

\begin{tabular}{|c|c|c|c|c|}
\hline Root & Afix & Derivation & Categories & Meaning \\
\hline $\begin{array}{l}\text { Keadilan } \\
\text { (justice) }\end{array}$ & $\begin{array}{c}\text { ke ... }+ \\
\ldots \text { an }\end{array}$ & $\begin{array}{l}\text { Keadilan } \\
\text { (justice) }\end{array}$ & Adjective & $\begin{array}{l}\text { Putting an unobtrusive } \\
\text { center in place, in } \\
\text { other words put } \\
\text { something in place. }\end{array}$ \\
\hline $\begin{array}{l}\text { Kejujuran } \\
\text { (honesty) }\end{array}$ & $\begin{array}{c}\text { ke ... }+ \\
\ldots \text { an }\end{array}$ & $\begin{array}{l}\text { Kejujuran } \\
\text { (honesty) }\end{array}$ & Adjective & $\begin{array}{l}\text { The part of the self- } \\
\text { esteem that must be } \\
\text { maintained because of } \\
\text { high value. }\end{array}$ \\
\hline $\begin{array}{l}\text { Kesantunan } \\
\text { (politeness) }\end{array}$ & $\begin{array}{c}\text { ke ... } \\
\ldots \text { an }\end{array}$ & $\begin{array}{l}\text { Kesantunan } \\
\text { (politeness) }\end{array}$ & Adjective & $\begin{array}{l}\text { The part of the self- } \\
\text { esteem that must be } \\
\text { maintained because of } \\
\text { high value. }\end{array}$ \\
\hline
\end{tabular}

Table 3: Ecolexicons of Phrases

\begin{tabular}{|c|c|c|c|c|c|}
\hline \multirow{2}{*}{ Ecolexicon } & \multirow{2}{*}{ Categories } & \multirow{2}{*}{$\begin{array}{l}\text { Core } \\
\text { Unit }\end{array}$} & \multirow{2}{*}{ Meaning } & \multicolumn{2}{|c|}{ Referent } \\
\hline & & & & Biotic & Abiotic \\
\hline $\begin{array}{l}\text { pilar } \\
\text { konservasi } \\
\text { (conservati } \\
\text { on pillar) }\end{array}$ & $\begin{array}{l}\text { Noun } \\
\text { Phrase }\end{array}$ & $\begin{array}{l}\text { Pilar } \\
\text { (pillar) }\end{array}$ & $\begin{array}{l}\text { Rules or behaviors } \\
\text { established and } \\
\text { mutually agreed } \\
\text { upon by a society. }\end{array}$ & - & Abiotic \\
\hline $\begin{array}{l}\text { prinsip } \\
\text { konservasi } \\
\text { (conservati } \\
\text { on } \\
\text { principles) }\end{array}$ & $\begin{array}{l}\text { Noun } \\
\text { Phrase }\end{array}$ & $\begin{array}{l}\text { Prinsip } \\
\text { (proncipl } \\
\text { e) }\end{array}$ & $\begin{array}{l}\text { The basis for } \\
\text { forming a good thing } \\
\text { is tangible or } \\
\text { intangible. }\end{array}$ & - & Abiotic \\
\hline $\begin{array}{l}\text { tugu } \\
\text { konservasi } \\
\text { (conservati } \\
\text { on tower) }\end{array}$ & $\begin{array}{l}\text { Noun } \\
\text { Phrase }\end{array}$ & $\begin{array}{l}\text { Tugu } \\
\text { (tower) }\end{array}$ & $\begin{array}{l}\text { Protection, } \\
\text { preservation, and } \\
\text { sustainable use, like } \\
\text { conservation of } \\
\text { natural resources, } \\
\text { environment, art and } \\
\text { culture. }\end{array}$ & - & Abiotic \\
\hline $\begin{array}{l}\text { konservasi } \\
\text { etika } \\
\text { (conservati } \\
\text { on ethics) }\end{array}$ & $\begin{array}{l}\text { Verbal } \\
\text { Phrase }\end{array}$ & $\begin{array}{l}\text { Konserva } \\
\text { si } \\
\text { (conserva } \\
\text { tion) }\end{array}$ & $\begin{array}{l}\text { Large and high poles } \\
\text { made of stone, } \\
\text { bricks, and so on as a } \\
\text { symbol of the State } \\
\text { University of } \\
\text { Semarang insightful } \\
\text { conservation }\end{array}$ & - & Abiotik \\
\hline $\begin{array}{l}\text { konservasi } \\
\text { nilai } \\
\text { (conservin } \\
g \text { values) }\end{array}$ & $\begin{array}{l}\text { Verbal } \\
\text { Phrase }\end{array}$ & $\begin{array}{l}\text { Konserva } \\
\text { si } \\
\text { (conserva } \\
\text { tion) }\end{array}$ & $\begin{array}{l}\text { Maintain and } \\
\text { preserve the } \\
\text { knowledge of what is } \\
\text { good and what is bad } \\
\text { about moral rights } \\
\text { and duties. }\end{array}$ & - & Abiotic \\
\hline
\end{tabular}




\begin{tabular}{lcclll}
\hline $\begin{array}{l}\text { salam } \\
\text { konservasi } \\
\text { (conservati } \\
\text { on }\end{array}$ & $\begin{array}{c}\text { Verbal } \\
\text { greetings) }\end{array}$ & $\begin{array}{c}\text { Salam } \\
\text { (greeting } \\
\text { ramah }\end{array}$ & $\begin{array}{l}\text { Maintain and } \\
\text { preserve those traits } \\
\text { that are important or } \\
\text { useful for humanity. }\end{array}$ & - & Abiotic \\
$\begin{array}{l}\text { lingkungan } \\
\text { (environme } \\
\text { ntally } \\
\text { friendly) }\end{array}$ & $\begin{array}{c}\text { Adjective } \\
\text { Phrase }\end{array}$ & $\begin{array}{c}\text { Lingkung } \\
\text { an } \\
\text { (environm } \\
\text { ent) }\end{array}$ & $\begin{array}{l}\text { Safe or not harm the } \\
\text { environment. }\end{array}$ & & \\
& & & & & Abiotic \\
\hline
\end{tabular}

\section{Ecolexicon Forms of Pillars of Art and Culture}

The pillar of art and culture is a conservation value that focuses on the preservation of art and culture, especially the culture of Central Java, and throughout Indonesia in general. Here are the ecolexic forms of the pillars of art and culture found in conservation news texts in Indonesian-language mass media.

Tabel 4: Ecolexicon of Words

\begin{tabular}{|c|c|c|c|c|}
\hline \multirow{2}{*}{ Ecolexicon } & \multirow{2}{*}{ Categories } & \multirow{2}{*}{ Meaning } & \multicolumn{2}{|c|}{ Referent } \\
\hline & & & Biotic & Abiotic \\
\hline Batik (custom) & Noun & $\begin{array}{l}\text { The picture fabrics are specially made } \\
\text { by wearing the night on the cloth. }\end{array}$ & - & Abiotic \\
\hline $\begin{array}{l}\text { Langgam } \\
\text { (custom) }\end{array}$ & Noun & The rhythm form of a song or song & - & Abiotic \\
\hline Seni (art) & Noun & $\begin{array}{l}\text { Works created with extraordinary } \\
\text { expertise }\end{array}$ & - & Abiotic \\
\hline $\begin{array}{l}\text { Wayang } \\
\text { (puppet) }\end{array}$ & Noun & $\begin{array}{l}\text { Artificial puppets made of bark } \\
\text { sculptures and so on that can be } \\
\text { exploited to wear characters in } \\
\text { traditional drama performances. }\end{array}$ & - & Abiotic \\
\hline
\end{tabular}

Table 5: Ecolexicon of Derivations

\begin{tabular}{|c|c|c|c|c|}
\hline Root & Afixes & Derivations & Categories & Meaning \\
\hline Budaya & ke $\ldots+\ldots$ an & Kebudayaan & Noun & $\begin{array}{l}\text { The result of human } \\
\text { activity and creation } \\
\text { (mind) such as belief, art, } \\
\text { and custom. }\end{array}$ \\
\hline Pesisir & $\ldots+\ldots$ an & Pesisiran & Nomina & $\begin{array}{l}\text { Knowledge possessed and } \\
\text { imbued by the Coastal } \\
\text { community, whose } \\
\text { contents are tools of } \\
\text { knowledge model that can } \\
\text { selectively be used to } \\
\text { understand and interpret } \\
\text { the environment at hand, } \\
\text { to encourage, and to } \\
\text { create the actions it needs. }\end{array}$ \\
\hline dalang & pe... $+\ldots$ an & Pedalangan & Noun & $\begin{array}{l}\text { Anything or knowledge } \\
\text { relating to story telling or } \\
\text { puppet show }\end{array}$ \\
\hline
\end{tabular}


Tabel 6: Ecolexicon of Phrases

\begin{tabular}{|c|c|c|c|c|c|}
\hline \multirow{2}{*}{ Ecolexicon } & \multirow{2}{*}{ Categories } & \multirow{2}{*}{ Core Unit } & \multirow{2}{*}{ Meaning } & \multicolumn{2}{|c|}{ Referent } \\
\hline & & & & Biotic & Abiotic \\
\hline $\begin{array}{l}\text { arak-arakan } \\
\text { budaya }\end{array}$ & $\begin{array}{l}\text { Noun } \\
\text { Phrase }\end{array}$ & $\begin{array}{c}\text { arak- } \\
\text { arakan } \\
\text { (processio } \\
n \text { ) }\end{array}$ & $\begin{array}{l}\text { Convoys of people and so } \\
\text { on who walk or move } \\
\text { together (parade) that is } \\
\text { the rampart of customs }\end{array}$ & - & Abiotic \\
\hline budaya luhur & $\begin{array}{l}\text { Noun } \\
\text { Phrase }\end{array}$ & $\begin{array}{l}\text { Budaya } \\
\text { (culture) }\end{array}$ & $\begin{array}{l}\text { Mind, reason, customs of } \\
\text { high value and noble }\end{array}$ & - & Abiotic \\
\hline sanggar tari & $\begin{array}{l}\text { Noun } \\
\text { Phrase }\end{array}$ & $\begin{array}{l}\text { Sanggar } \\
\text { (studio) }\end{array}$ & $\begin{array}{l}\text { Means, containers for } \\
\text { creativity and familiar with } \\
\text { traditional dances, from } \\
\text { various regions, which are } \\
\text { complicated and modified } \\
\text { to better master and get to } \\
\text { know more closely the } \\
\text { traditional dance }\end{array}$ & - & Abiotic \\
\hline tari sekaringrat & $\begin{array}{l}\text { Noun } \\
\text { Phrase }\end{array}$ & $\begin{array}{c}\text { Tari } \\
\text { (dance) }\end{array}$ & $\begin{array}{l}\text { One of UNNES } \\
\text { innovations in the form of } \\
\text { dance that symbolizes } \\
\text { conservation in every } \\
\text { movement }\end{array}$ & - & Abiotic \\
\hline $\begin{array}{l}\text { gending } \\
\text { konservasi }\end{array}$ & $\begin{array}{l}\text { Noun } \\
\text { Phrase }\end{array}$ & Gending & $\begin{array}{l}\text { Instruments or songs } \\
\text { expressed by conservation- } \\
\text { themed tones. }\end{array}$ & - & Abiotic \\
\hline selasa legen & $\begin{array}{l}\text { Noun } \\
\text { Phrase }\end{array}$ & $\begin{array}{l}\text { Selasa } \\
\text { (Tuesday) }\end{array}$ & $\begin{array}{l}\text { Day with the market } \\
\text { according to Javanese } \\
\text { custom }\end{array}$ & - & Abiotic \\
\hline
\end{tabular}

\section{Ecolexicon Forms of Pillars of Natural Sources and Environment}

Pillar of natural resources and environment is the value of conservation related to environmental ecosystem balance. Here are the ecolexic forms of the pillars of natural and environmental resources found in conservation news texts in Indonesian-language mass media.

Table 7: Ecolexicon of Words

\begin{tabular}{lclcc}
\hline \multirow{2}{*}{ Ecolexicons } & Categories & \multicolumn{1}{c}{ Meaning } & \multicolumn{2}{c}{ Referent } \\
Biotic & Abiotic \\
\hline kompos & Noun & $\begin{array}{l}\text { Mixed fertilizers consisting of } \\
\text { organic materials (such as } \\
\text { decaying leaves and straw) and } \\
\text { animal waste }\end{array}$ & - & Abiotic \\
\hline
\end{tabular}




\begin{tabular}{|c|c|c|c|c|}
\hline biopori & Noun & $\begin{array}{l}\text { Absorbent absorption holes, with } \\
\text { predetermined specified sizes that } \\
\text { are covered with organic waste } \\
\text { that serves as a water absorber to } \\
\text { the ground and make natural } \\
\text { compost. }\end{array}$ & - & Abiotic \\
\hline konservasi & Noun & $\begin{array}{l}\text { Maintenance and protection of } \\
\text { something regularly to prevent } \\
\text { damage and destruction by } \\
\text { preservation, maintenance, and } \\
\text { preservation }\end{array}$ & - & Abiotic \\
\hline durian & Noun & $\begin{array}{l}\text { Name of one type of tree and its } \\
\text { fruit (flora) }\end{array}$ & Biotic & - \\
\hline eduwisata & Noun & $\begin{array}{l}\text { Tour to deepen or better } \\
\text { understand an object to add } \\
\text { insight and knowledge }\end{array}$ & - & Abiotic \\
\hline trembesi & Noun & $\begin{array}{l}\text { Large and fast-growing trees, the } \\
\text { crown of leaves resemble } \\
\text { umbrellas and widths, widely } \\
\text { planted for giving shade, the } \\
\text { wood is not very durable, the } \\
\text { leaves are used as animal feed, } \\
\text { the fruit is thick and fleshy pods; } \\
\text { Wood ambon; Munggur; } \\
\text { Enterolobium saman }\end{array}$ & Biotic & - \\
\hline asri & Adjective & $\begin{array}{l}\text { Beautiful and good looking } \\
\text { Things related to herbs-plants }\end{array}$ & - & Abiotic \\
\hline herbal & Adjective & $\begin{array}{l}\text { that leaves, flowers, or roots can } \\
\text { be used for food herbs, } \\
\text { medicines, or perfume. }\end{array}$ & - & Abiotic \\
\hline organik & Adjective & $\begin{array}{l}\text { With regard to substances derived } \\
\text { from living things (animals or } \\
\text { plants, such as oil and coal) }\end{array}$ & - & Abiotic \\
\hline anorganik & Adjective & $\begin{array}{l}\text { With regard to or characterized } \\
\text { by the absence of living } \\
\text { organisms }\end{array}$ & - & Abiotic \\
\hline
\end{tabular}

Table 8: Ecolexicons of Derivations

\begin{tabular}{|c|c|c|c|c|}
\hline Root & Affix & Derivation & Categories & Meaning \\
\hline sejuk & ke- + -an & kesejukan & Noun & $\begin{array}{l}\text { Subject (state and so } \\
\text { on) which is cool }\end{array}$ \\
\hline pohon & pe -+ -an & pepohonan & Noun & Trees; many trees \\
\hline panas & pe- + -an & $\begin{array}{l}\text { pemanasan } \\
\text { (global) }\end{array}$ & Noun & $\begin{array}{l}\text { Process, manner, act of } \\
\text { heating or heating }\end{array}$ \\
\hline tanam & $\ldots+$ an & Tanaman & Noun & $\begin{array}{l}\text { Plants that people } \\
\text { usually grow; Yield of } \\
\text { planting; Planted }\end{array}$ \\
\hline
\end{tabular}


Table 9: Ecolexicons of Phrase

\begin{tabular}{|c|c|c|c|c|c|}
\hline \multirow{2}{*}{ Ecolexicon } & \multirow{2}{*}{ Categories } & \multirow{2}{*}{ Core Unit } & \multirow{2}{*}{ Meaning } & \multicolumn{2}{|c|}{ Referent } \\
\hline & & & & Biotic & Abiotic \\
\hline $\begin{array}{l}\text { rimbun } \\
\text { pepohonan }\end{array}$ & $\begin{array}{l}\text { Noun } \\
\text { phrase }\end{array}$ & pepohonan & Trees & Biotic & - \\
\hline $\begin{array}{l}\text { pemanasan } \\
\text { global }\end{array}$ & $\begin{array}{l}\text { Noun } \\
\text { phrase }\end{array}$ & pemanasan & $\begin{array}{l}\text { The rising } \\
\text { temperatures of Earth's } \\
\text { atmosphere caused by } \\
\text { the increase of } \\
\text { pollutant gases such as } \\
\text { carbon dioxide }\end{array}$ & - & Abiotic \\
\hline $\begin{array}{l}\text { bendungan } \\
\text { mini }\end{array}$ & $\begin{array}{l}\text { Noun } \\
\text { phrase }\end{array}$ & bendungan & $\begin{array}{l}\text { Retaining buildings or } \\
\text { landfills for irrigation } \\
\text { (power plants, etc.) of } \\
\text { small size. }\end{array}$ & - & Abiotic \\
\hline nir kertas & $\begin{array}{l}\text { Noun } \\
\text { phrase }\end{array}$ & kertas & $\begin{array}{l}\text { Not using or } \\
\text { minimizing paper } \\
\text { usage }\end{array}$ & - & Abiotic \\
\hline $\begin{array}{l}\text { kampus } \\
\text { konservasi }\end{array}$ & $\begin{array}{l}\text { Noun } \\
\text { phrase }\end{array}$ & kampus & $\begin{array}{l}\text { Conservation campus } \\
\text { is a university that in } \\
\text { the implementation of } \\
\text { education, research, } \\
\text { and community service } \\
\text { has a concept that } \\
\text { refers to the principles } \\
\text { of conservation } \\
\text { (protection, } \\
\text { preservation, and } \\
\text { sustainable use) both } \\
\text { conservation of natural } \\
\text { resources, } \\
\text { environment, art, and } \\
\text { culture. }\end{array}$ & - & Abiotic \\
\hline & & & $\begin{array}{l}\text { One of the gymnastics } \\
\text { innovations from }\end{array}$ & & Abiotic \\
\hline $\begin{array}{l}\text { senam } \\
\text { konservasi } \\
\text { (conservatio } \\
\text { n gymnastic) }\end{array}$ & $\begin{array}{l}\text { Noun } \\
\text { phrase }\end{array}$ & senam & $\begin{array}{l}\text { UNNES by using } \\
\text { musical } \\
\text { accompaniment of } \\
\text { gending conservation } \\
\text { with a combination of } \\
\text { gymnastics movement }\end{array}$ & - & \\
\hline kader & & & $\begin{array}{l}\text { The expected person } \\
\text { will play an important }\end{array}$ & & Abiotic \\
\hline $\begin{array}{l}\text { konservasi } \\
\text { (conservatio } \\
\text { n cadres) }\end{array}$ & $\begin{array}{l}\text { Noun } \\
\text { phrase }\end{array}$ & kader & $\begin{array}{l}\text { role in the effort to } \\
\text { realize the } \\
\text { conservation campus }\end{array}$ & - & \\
\hline
\end{tabular}




\begin{tabular}{|c|c|c|c|c|c|}
\hline $\begin{array}{l}\text { wawasan } \\
\text { konservasi } \\
\text { (horizon of } \\
\text { conservation) }\end{array}$ & $\begin{array}{l}\text { Noun } \\
\text { phrase }\end{array}$ & konservasi & $\begin{array}{l}\text { Have a conception or } \\
\text { perspective on the } \\
\text { maintenance and } \\
\text { protection of } \\
\text { something regularly to } \\
\text { prevent damage and } \\
\text { destruction by } \\
\text { preservation, } \\
\text { preservation, and } \\
\text { preservation of the } \\
\text { environment }\end{array}$ & - & Abiotic \\
\hline $\begin{array}{l}\text { nilai } \\
\text { konservasi } \\
\text { (conservatio } \\
n \text { value) }\end{array}$ & $\begin{array}{l}\text { Noun } \\
\text { phrase }\end{array}$ & konservasi & $\begin{array}{l}\text { Pricing or appraisal } \\
\text { (things) that are } \\
\text { important or useful for } \\
\text { humanity regarding } \\
\text { regular maintenance } \\
\text { and protection of } \\
\text { something to prevent } \\
\text { damage and } \\
\text { destruction by } \\
\text { preservation, } \\
\text { preservation, and } \\
\text { preservation of the } \\
\text { environment }\end{array}$ & - & Abiotic \\
\hline $\begin{array}{l}\text { kampus hijau } \\
\text { (green } \\
\text { campus) }\end{array}$ & $\begin{array}{l}\text { Noun } \\
\text { phrase }\end{array}$ & kampus & $\begin{array}{l}\text { The movement to } \\
\text { realize the area of the } \\
\text { main building } \\
\text { environment of college } \\
\text { becomes more } \\
\text { beautiful and } \\
\text { comfortable place by } \\
\text { doing conservation } \\
\text { efforts (tree planting, } \\
\text { etc.) }\end{array}$ & - & Abiotic \\
\hline $\begin{array}{l}\text { penghijauan } \\
\text { kampus } \\
\text { (geening the } \\
\text { campus) }\end{array}$ & $\begin{array}{l}\text { Noun } \\
\text { Phrase }\end{array}$ & kampus & $\begin{array}{l}\text { Processes, ways, } \\
\text { actions make the } \\
\text { campus environment } \\
\text { green by planting trees } \\
\text { to keep the air cool and } \\
\text { clean. }\end{array}$ & - & Abiotic \\
\hline $\begin{array}{l}\text { gerakan } \\
\text { menanam } \\
\text { (Planting } \\
\text { movement) }\end{array}$ & $\begin{array}{l}\text { Frasa } \\
\text { Verbal }\end{array}$ & planting & $\begin{array}{l}\text { Movement, business, } \\
\text { or planting activities as } \\
\text { a reforestation / } \\
\text { conservation effort } \\
\text { Movement, business, } \\
\text { or planting activities as } \\
\text { a reforestation / } \\
\text { conservation effort }\end{array}$ & - & Abiotic \\
\hline
\end{tabular}




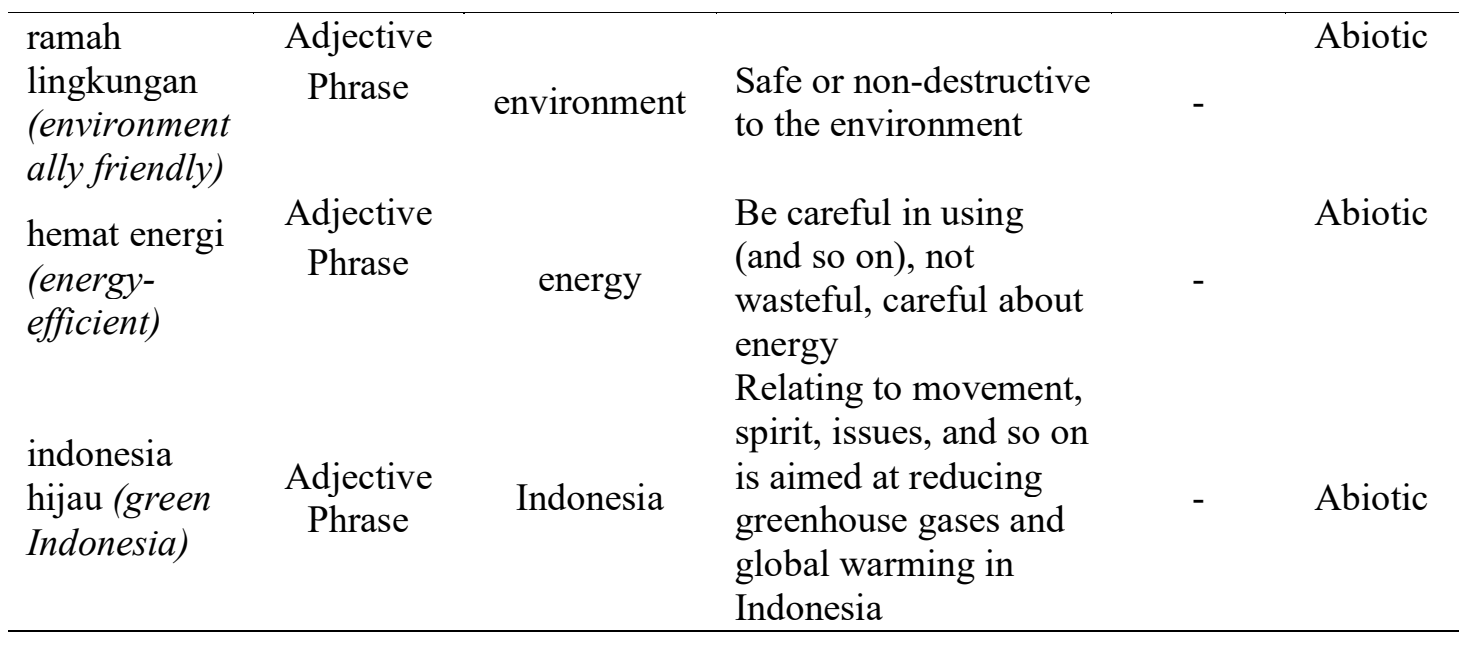

From the above data indicates that regardless of the scope of the pros and cons, agree or disagree over the declared conservation university policy, the issues that need to be noticed that the conservation news text in Indonesian mass media is a lingual phenomenon. This is because in the conservation news text there is consololaxic conservation in the form of words and phrases. In addition, there are also styles of language, eufimisme, metofora, and personification.

Schultz (in Fill \&Muhlhauster 2001, pp.109-110) states that there are three linguistic or linguistic tools that are often used in texts related to the commercialization of the environment. First, the use of neutral words that have the connotation of praise or tend to side with exploitation, but the reality represented by the word is very different. For example, the use of words or terms ecologically sustainable development, fertilizer and human resources. Secondly, the tools that are often used, namely the use of euphemism (the mention of objects or something unpleasant to be more polite). For example, the use of the term clearing, harvest, greenhouse effect and global warming. Third, rarely used tools but very powerful effects when used, ie the use of peyorative terms or dysphism (mention of a sign or something with a more negative connotation). For example, the use of word or term earthworm food and animal's homes to mention humus.

Language researchers may indeed choose one of a number of linguistic aspects to examine, in microlinguistic or macro-linguistic umbrellas, theoretical linguistics or pure linguistics or applied linguistics. Both are just as important. Pure linguistics (mikrolinguistik) is very important to be developed through indepth research for the development of linguistic theory, including Indonesian linguistics and Indonesian languages as it will in turn sustain the development and development of applied linguistics. According to Mbete (2003, p.14), many linguistic, micro and macro, pure and applied issues, monodisciplinary and interdisciplinary, especially under the umbrella of ecolinguistics, are interesting to be identified and developed in research.

\section{Conclusion}

Ecolinguistics as a paradigm of a relatively new approach is worth developing. This interdisciplinary linguistic umbrella, if developed more empirically, factually, and conceptually, can be a source of inspiration in 
identifying the various environmental issues around us, in the effort to dissect mutual relationships between people, humans and nature, as well as about the diversity itself. In conservative news text in Indonesian mass media, ecolexicoon is found based on the pillars of values and character, art and culture, Natural Resources and environment that are affiliated with biotic and abiotic in the form of: (a) the base word, (b) derivative word, (c) Noun phrases, verbal phrases, adjective phrases. In conservation news text also found the existence of euphemism, metaphor, personification.

The study of ecolinguistics in the conservation news texts in Indonesian mass media can provide theoretical and practical benefits, namely: (1) providing description of the analysis of the forms, meanings, types, and functions of lingual units that combine ideological, sociological and biological dimensions; (2) providing instructional materials in the form of news texts, especially conservation news text --- green text on conservation --- which is one type of text in the basic competencies of the curriculum; (3) providing an interdisciplinary study of inter-disciplinary consolidation texts to strengthen the theory and methods of journalistic and linguistic studies; and (4) providing input to media managers in the reality of news about conservation in the media and for news sources as input when interacting with the media.

\section{References}

Al G., \& Usman, Y. (2012). Ekolinguistik. Jakarta: Pang Linge.

Al-Sharabi, A., Ibrahim, N., \& Nor, N. F. M. (2011). Representation of nojoud's 'early'marriage: A cda of online english-language yemeni newspapers. Journal of Language Studies, 11(1).

Bolte, S., \& Keong, Y. C. (2014). The refugee swap deal in malaysian online news reports: Ideology and representation. Journal of Language Studies, 14(2).

Crystal. (2008). A Dictionary of Languistics and Phonetic (6th ed.). United Kingdom: Blackwell Publishing

Fill, A., \& Mühlhäusler, P. (2001). The ecolinguistics reader language, ecology, and environment. London: Continuum.

Gibbons, M.T. (Ed). (2002). Tafsir politik interpretasi hermeneutis wacana sosial-politik kontemporer. Yogyakarta: Qalam.

Haugen, E. (1972). The ecolinguistics reader language, ecology, and environment (Fill, A., \& Mühlhäusler, P., Eds). London: Continuum.

Kesuma, D. (2015). Keterancaman leksikon ekoagraris dalam bahasa angkola/mandailing: Kajian ekolinguistik. Jurnal Kajian Linguistik, 12(1), 54-76.

Kesuma, T.M.J. (2007). Pengantar (metode) penelitian bahasa. Yogyakarta: Caravatibooks.

Kress, G. (2010). Bahasa, citra, media. Yogyakarta: Jalasutra.

Kridalakasana, H. (1989). Pembentukan kata dalam bahasa Indonesia. Jakarta: Gramedia.

Lindo., Vibeke, A., \& Bundsgaard, J (Eds). (2000). Dialectical ecolinguistics three essays for the symposium 30 years of language and ecology in graz december 2000. Austria: Univerisity of Odense Research Group for Ecology, Language and Ecology. 
Mahsun. (2005). Metode penelitian bahasa: Tahapan strategi, metode, dan tekniknya. Jakarta: Raja Grafindo Persada.

Mbete, A.M. (2002). Ungkapan-ungkapan dalam bahasa dan fungsinya dalam melestarikan lingkungan. Linguistika, 9(17), 174-186.

Moleong, L.J. (2007). Metodologi penelitian kulitatif. Bandung: Remaja Rosdakarya.

Rokhman, Fathur, \& Surahmat. (2016). Politik bahasa penguasa. Jakarta: Kompas.

Rustono. (1999). Pokok-pokok pragmatik. Semarang: IKIP Semarang Press.

Stibbe, A. (2010). Ecolinguistics and globalisation. London: Blackwell.

Sudaryanto. (2015). Metode dan aneka teknik analisis bahasa: Pengantar penelitian wahana kebudayaan secara linguistis. Yogyakarta: Duta Wacana University Press.

Sugiyono. (2012). Metode penelitian pendidikan pendekatan kuantitatif, kualitatif, dan $R \& D$. Bandung: Alfabeta.

Suhandang, K. (2004). Organisasi, produk, dan kode etik jurnalistik. Bandung: Yayasan Nuansa Cendekia.

Vo, D.D. (2013). Language and ideology in english and vietnamese business hard news reporting-a comparative study. Journal of English Language Studies, 19(2).

Wijana, I.D.P. (2010). Pengantar semantik Bahasa Indonesia. Yogyakarta: Pustaka Pelajar. 